\title{
動荷重下におけるワイヤロープの強度についで
}

\author{
藤 井健 也林根来広平**
}

\section{Strength of Wire Rope under Dynamic Load}

by

\section{Kenya FuJII and Hirohei NEGORO}

(Toyo Wire Rope Mfg. Co. Ltd.)

In order to investigate the behavior of wire rope under the dynamic load, we experimented with a drop hammer type impact tester, which was of our own design, and discussion was made on the impact breaking strength and the absorption of energy of wire ropes, comparing with those obtained by static tests.

In this paper we report how the breaking strength and absorption of energy are influenced by the impact speed and the length of wire rope. The results can be summarized as follows :

Under the test conditions:

Length of wire rope varying from $500 \mathrm{~mm}$ to $2000 \mathrm{~mm}$,

Impact speed varying from $3.8 \mathrm{~m} / \mathrm{s}$ to $6.9 \mathrm{~m} / \mathrm{s}$,

1) As the impact speed is increased or as the specimen becomes shorter, the breaking strength increases.

2) As the impact speed is increased or as the specimen becomes shorter, the inclination of stress-strain diagram augments, and absorption of energy decreases.

3) Absorption of energy is not so markedly influenced by the impact speed within the range of this experiments, but when the rope is extremely short, then it decreases very rapidly.

(Received July 9, 1963)

\section{1. 緒}

言

静荷重下におけるワイヤロープの強度については従 来種々研究され論じられてきたが，実際ロープは衝撃 荷重を受ける場合が多く，これに対する究明はロープ の製作および使用にあたって，重要なる研究課題の一 つである。しかし，われわれの知る限りでは，これに 関する研究はほとんど行なわれていない現状にあるの で, 新たに衝撃試験機を設計し, 動荷重下にお㳡るワ イヤロープの強度ならびに切断エネルギを求め, それ らの值が試料長さあるいは衝撃速度によってどのよう に変化するかを明らかにし, 静荷重の場合と比軹検討 を行なった。

\section{2. 衝撃試験機の構造}

本衝撃試験機は 4 本の部材を垂直に立てた門形ラー メンの中央部に試料ロープをつり下げ，下端に受盤を 取り付けて重錘をある高さから落下させ，受盤を打撃 してロープに衝撃荷重を与えるような構造である。地 上 $5000 \mathrm{~mm}$ の高さにある天床は I ビームで補強され ており，これからストレンゲーヂを内蔵せるロードセ

* 原稿受付 昭和 38 年 7 月 9 日

*正員 東洋製綱铢式会社
ルを介して試料をつり下げる。

試料ロープの両端は鋳込久ソケットを行ない，ロー プの下端にはソケットを介して受盤がつり下げられる。 ロープにはホワイトメタルとソケットの重量 $25 \mathrm{~kg}$ と 受盤の重量 $1.07 \mathrm{~kg}$ の計 $1.32 \mathrm{~kg}$ がつり下げられ, 初張 力となる。また重鍾の全重量は $1000 \mathrm{~kg}$ とし，2本の 径 $10 \mathrm{~mm}$ のワイヤロープでつり，塔の上部にある 2 個シーブを通ってからこれを 1 本の径 $14 \mathrm{~mm}$ のロー プに連結し，ウインチに巻さ取る。ロープに対する衝 撃荷重はこのウインチを用いて重鍾を所定の高さにま で上げた後，クラッチを外して重錘を落下させ，受盤

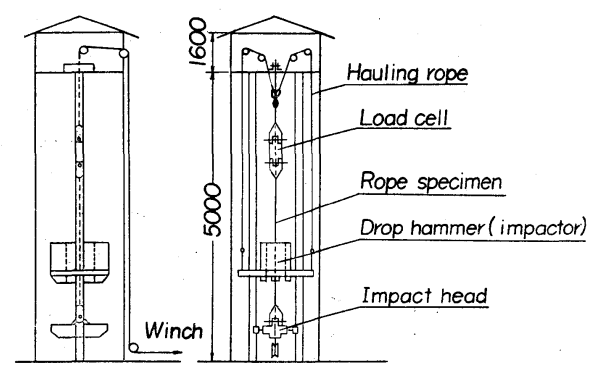

Fig. 1 Drop hammer type impact machine 
を打撃して与える。試験機の主要構造は Fig. 1 に示 すとうりである。

\section{3. 測 定 方 法}

ロープを衝撃切断する場合の荷重の測定は, 試験機 の天床における固定点と試料ロープ端のソケット間に ロードセルを㨂入し，動ひずみ測定器を電磁オシロと 組み合せて測定した．また，伸びの測定は Fig. 2 に 示すように $14.0 \mathrm{~mm}$ 間隔に 11 個のスリットを有する 格子を重鉏の下端に取り付け，重錘が受盤に接した時， ラーメン下部に取り付けた収光レンズよりの光束がこ のスリットを通過し，焦点をフォートトランジスタに 結ぶように光源, 収光レンズ, フォートトランジスタ を一直線上に配置し，重鍾落下に伴う光束のスリット 通過状況をオシログラフに自記せしめ，動ひずみ計と 連動して測定した。

測定器具仕様の概要は次のとおりである。

(1) ロードセル

新興通信工業 K.K. 製 : LT-20 型

使用ゲージ：ベークライトゲージ 8 枚

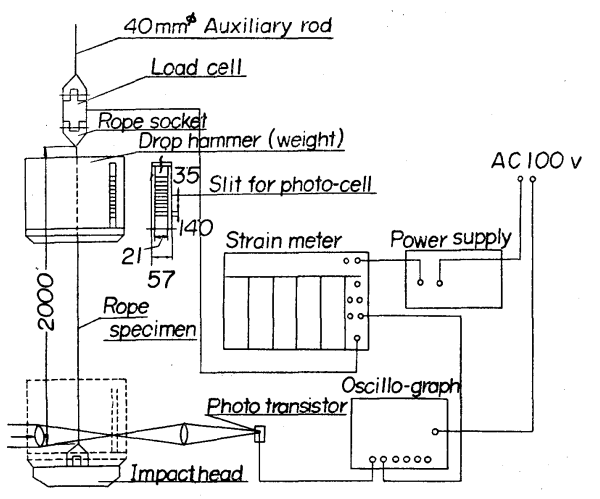

Fig. 2 Detail of measuring apparatus
ブリッジの抵抗 : $120 \Omega$

（2）動ひずみ測定器

新興通信工業 K.K. 製：DS 6-R 型

発振周波数 : $4950 \mathrm{c} / \mathrm{s}$

(3) 電磁オシログラフ

三栄测定器 K.K. 製 : 100-A 型

固有周波数 : $300 \mathrm{c} / \mathrm{s}$

(4) フォートトランジスタ

松下電器産業 K.K. 製 : MCP-71 型

\section{4. 試料ならびに実験方法}

試料は JIS 規格による $6 \times 7,6 \times 19,6 \times \mathrm{Fi}(19+6)$ の 3 種類を用いて長さおよび衝撃速度をおのおの

Table 1 に示す範囲で変化させて実験した.

各試料はおのおの所定の長さの位置にシージングを 行ない，その両端を鋳込ソケットした後，上端をロー ドセルに直結した。

衝撃速度は重錘落下高さ在变化させることにより， 打撃瞬間における落下速度をもって表わすこととした。 試験はすべて電磁オシロを用いて, 時間一荷重曲線,

Table 1 Test condition

\begin{tabular}{l|c|c}
\hline $\begin{array}{c}\text { Construction and } \\
\text { dia. of rope }(\mathrm{mm})\end{array}$ & $\begin{array}{c}\text { Rope length } \\
(\mathrm{mm})\end{array}$ & $\begin{array}{c}\text { Impact speed } \\
(\mathrm{m} / \mathrm{s})\end{array}$ \\
\hline & & $3 \cdot 8 \sim 4 \cdot 0$ \\
& 1000 & $5 \cdot 4 \sim 5 \cdot 7$ \\
$6 \times 70 / \mathrm{L} 16$ & & $6 \cdot 6 \sim 6 \cdot 9$ \\
$6 \times 19 \% \quad 16$ & 2000 & \\
\hline $6 \times \mathrm{Fi}(19+6) \% 16$ & 1000 & $5 \cdot 4 \sim 5 \cdot 7$ \\
& 500 & \\
\hline
\end{tabular}

Table 2 Effect of rope length on Its impact breaking strength

\begin{tabular}{|c|c|c|c|c|c|c|}
\hline \multirow{2}{*}{$\begin{array}{l}\text { Construction and } \\
\text { dia. of rope } \\
(\mathrm{mm})\end{array}$} & \multirow{2}{*}{$\begin{array}{c}\begin{array}{c}\text { Rope } \\
\text { length }\end{array} \\
\text { (mm) }\end{array}$} & \multirow{2}{*}{$\frac{\underset{\text { speed }}{\text { Impact }}}{(\mathrm{m} / \mathrm{s})}$} & \multirow{2}{*}{$\begin{array}{l}\text { Breaking } \\
\text { strength } \\
(\mathrm{kg})\end{array}$} & \multicolumn{2}{|c|}{ Elongation } & \multirow{2}{*}{$\begin{array}{l}\text { Loading time } \\
(1 / 100 \mathrm{sec})\end{array}$} \\
\hline & & & & $(\mathrm{mm})$ & $(\%)$ & \\
\hline \multirow[b]{2}{*}{$6 \times 7 \quad 0 / \mathrm{L} \quad 16$} & 2000 & $5 \cdot 45$ & 17030 & $59 \cdot 0$ & $2 \cdot 95$ & $1 \cdot 47$ \\
\hline & 1000 & $5 \cdot 45$ & 17760 & $37 \cdot 3$ & $3 \cdot 73$ & 0.89 \\
\hline \multirow{3}{*}{$6 \times 19 \% 16$} & 2000 & $5 \cdot 60$ & 15570 & $64 \cdot 1$ & $3 \cdot 21$ & $1 \cdot 45$ \\
\hline & 1000 & $5 \cdot 45$ & 15770 & $34 \cdot 4$ & $3 \cdot 44$ & 0.74 \\
\hline & 500 & $5 \cdot 40$ & 18250 & $20 \cdot 9$ & $4 \cdot 18$ & 0.45 \\
\hline $6 \times \mathrm{Fi}(19+6) \% 16$ & 500 & $5 \cdot 45$ & 19380 & $22 \cdot 2$ & $4 \cdot 44$ & 0.46 \\
\hline
\end{tabular}


時間一伸び曲線を記録し，これらの線図から伸びー荷重 曲線を作図して静切断の場合を含めて, 切断荷重, 伸 びおよび切断ェネルギを比較することにした。なお実 験に先立ち, 各試料共構造上の伸びを除去するため, 各規格切断荷重の $40 \%$ の荷重にて 1.5 分間繰り返し 2 回のプリテンションを施した.

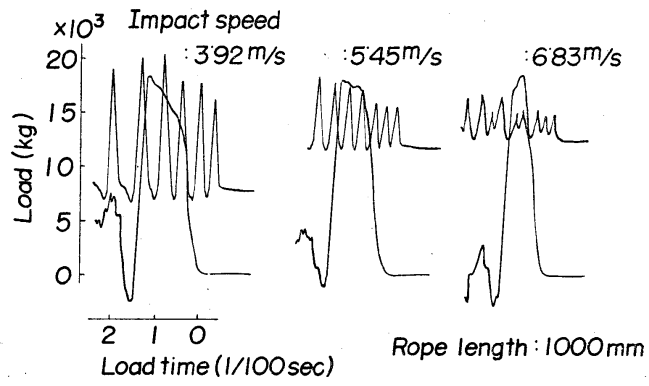

Fig. 3 Aspects of oscillo-diagram of $6 \times 7$ rope with above lengths

\section{5. 実 験 結 果}

（I）引張強度および伸びの变化

長さおよび衝撃速度を変化させた場合の衝撃荷重に よる各試料の切断荷重および伸びの変化はそれぞれ Table 2, 3 に示すとおりであって, 測定值は各 5 本 宛の試料についての平均值で現わした。

なお $6 \times 7$ ロープについてのオシロ自記記録を Fig.

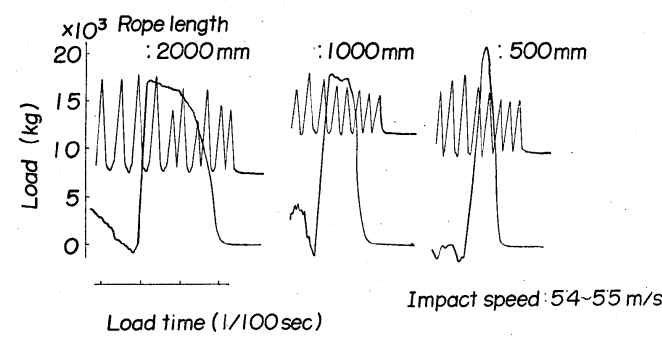

Fig. 4 Aspects of oscillo-diagram of $6 \times 7$ rope with above impact speeds

Table 3 Variation of breaking strength with impact speed

\begin{tabular}{|c|c|c|c|c|c|c|}
\hline \multirow{2}{*}{$\begin{array}{l}\text { Construction and } \\
\text { dia. of rope } \\
(\mathrm{mm})\end{array}$} & \multirow{2}{*}{$\begin{array}{l}\text { Height of } \\
\text { weight } \\
\text { (m) }\end{array}$} & \multirow{2}{*}{$\begin{array}{c}\text { Impact } \\
\text { speed }\end{array}$} & \multirow{2}{*}{$\begin{array}{c}\text { Breaking } \\
\text { strength }\end{array}$} & \multicolumn{2}{|c|}{ Elongation } & \multirow{2}{*}{$\begin{array}{l}\text { Loading time } \\
(1 / 100 \mathrm{sec})\end{array}$} \\
\hline & & & & $(\mathrm{mm})$ & $(\%)$ & \\
\hline \multirow{3}{*}{$6 \times 7 \quad 0 / L \quad 16$} & $3 \cdot 0$ & $6 \cdot 83$ & 18390 & $34 \cdot 2$ & $3 \cdot 42$ & $0 \cdot 63$ \\
\hline & $2 \cdot 0$ & $5 \cdot 45$ & 17760 & $37 \cdot 3$ & $3 \cdot 73$ & 0.89 \\
\hline & $1 \cdot 0$ & 3.92 & 17690 & $38 \cdot 8$ & $3 \cdot 88$ & $1 \cdot 21$ \\
\hline \multirow{3}{*}{$6 \times 19 \% 16$} & $3 \cdot 0$ & $6 \cdot 66$ & 16280 & $32 \cdot 5$ & $3 \cdot 25$ & 0.51 \\
\hline & $2 \cdot 0$ & $5 \cdot 46$ & 15770 & $34 \cdot 4$ & $3 \cdot 44$ & 0.74 \\
\hline & $1 \cdot 0$ & $3 \cdot 83$ & 15560 & $36 \cdot 6$ & $3 \cdot 66$ & $1 \cdot 18$ \\
\hline \multirow{3}{*}{$6 \times \mathrm{Fi}(19+6) \% 16$} & $3 \cdot 0$ & $6 \cdot 68$ & 17560 & $31 \cdot 9$ & $3 \cdot 19$ & 0.57 \\
\hline & $2 \cdot 0$ & $5 \cdot 35$ & 16880 & $34 \cdot 9$ & $3 \cdot 49$ & 0.87 \\
\hline & $1 \cdot 0$ & $3 \cdot 88$ & 16700 & $39 \cdot 0$ & $3 \cdot 90$ & $1 \cdot 19$ \\
\hline
\end{tabular}

Table 4 Variation of static breaking strength with rope length

\begin{tabular}{|c|c|c|c|c|c|}
\hline \multirow{2}{*}{$\begin{array}{c}\text { Construction and } \\
\text { dia. of rope } \\
(\mathrm{mm})\end{array}$} & \multirow{2}{*}{$\begin{array}{c}\text { Rope length } \\
(\mathrm{mm})\end{array}$} & \multirow{2}{*}{$\begin{array}{c}\begin{array}{c}\text { Breaking } \\
\text { strength }\end{array} \\
(\mathrm{kg})\end{array}$} & \multirow{2}{*}{$\frac{\begin{array}{c}\text { Breaking } \\
\text { strength (JIS) }\end{array}}{(\mathrm{kg})}$} & \multicolumn{2}{|c|}{ Elongation } \\
\hline & & & & $(\mathrm{mm})$ & (\%) \\
\hline \multirow{3}{*}{$\begin{array}{lllllllll}6 \times 7 & 0 / \mathrm{L} & 16\end{array}$} & 2000 & 16850 & 15000 & $80 \cdot 8$ & $4 \cdot 04$ \\
\hline & 1000 & 16850 & $\prime \prime$ & $44 \cdot 9$ & $4 \cdot 49$ \\
\hline & 500 & 16950 & $" \prime$ & $26 \cdot 8$ & $5 \cdot 36$ \\
\hline \multirow{3}{*}{$6 \times 19 \% 16$} & 2000 & 15100 & 14900 & $80 \cdot 9$ & $4 \cdot 05$ \\
\hline & 1000 & 15100 & $"$ & $47 \cdot 4$ & $4 \cdot 74$ \\
\hline & 500 & 15200 & $" \prime$ & $31 \cdot 6$ & $6 \cdot 32$ \\
\hline \multirow{3}{*}{$6 \times \mathrm{Fi}(19+6) \% 16$} & 2000 & 15400 & 15100 & $55 \cdot 8$ & $2 \cdot 79$ \\
\hline & 1000 & 15200 & $"$ & $30 \cdot 0$ & $3 \cdot 00$ \\
\hline & 500 & 15200 & " & $20 \cdot 8$ & $4 \cdot 16$ \\
\hline
\end{tabular}


3 および Fig. 4 に示した.

次に50 t アムスラ形引張試験機を用いて静引張試験 を行ない，長さを変化させた場合の切断荷重および伸 びの変化を測定した，結果は Table 4 に示すとおり であって, 測定值は各 3 本宛の試料についての平均值 であらわした。

実験の結果から動荷重を受けてロープが切断する場 合，いずれも衝撃速度が大になるほど，かつ長さが短 くなるほど切断荷重は上昇するが，特に長さ $500 \mathrm{~mm}$ および衝撃速度 $7 \mathrm{~m} / \mathrm{s}$ 程度で急激に上昇を示した。 た伸びは長さ一定の場合，いずれも衝撃速度の増加に 従って明らかに減少を示したが， $6 \times \mathrm{Fi}(19+6)$ ロープ では静引張の場合に比べて衝撃引張においては逆に増 加を示した. 切断荷重, 伸びの変化の度合はいずれも 構造によって異なるが，切断荷重に関しては，衝撃速 度によるよりも長さの変化により明りょうに変化が認 められた。しかし, 静引張では長さを変化させた場合 も予期したとおり，切断荷重に変化はなかった。
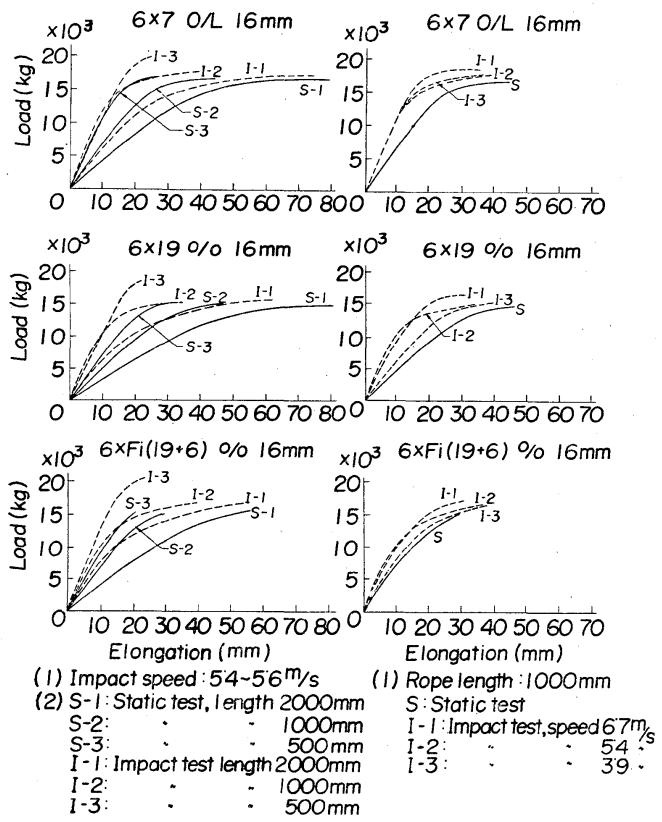

Fig. 5 Stress-strain diagram under impact test comparing with static test

\section{(II) 切断エネルギの変化}

オシロ自記記録による時間一伸び-一荷重関係曲線より， 衝撃引張における伸び一荷重曲線を求め, 静引張の場 合と比較して Fig. 5 に示すとともに長さ, 衝撃速度 の変化による衝撃引張下の切断エネルギの変化を Table 5 および Table 6 に示した.

静引張の場合に比べて衝撃引張の場合は一般に曲線 の傾きが大になり，切断に至るまでのェネルギは減少 を示したが, $6 \times \mathrm{Fi}(19+6)$ ロープでは逆に増加を示し た。また，本実験の範囲内では衝撃速度は切断ェネル ギに対して明りょうな影響走さなかったが，長さの 短縮に対してはエネルギが等比的に減少する傾向を示 した.

\section{6. 実験結果の考察}

動荷重下におけるワイヤロープの切断が衝撃速度ま たは長さによってどのように影響されるかを検討した が, 試験機の構造上衝撃速度は $4 \sim 7 \mathrm{~m} / \mathrm{s}$ 程度以上変 化し得なかったので結果は長さを变化させた場合の力 が明りょうに現われた。

\section{（I）衝撃速度を変化した場合}

一般に衝撃速度の上昇とともに伸び一荷重曲線の傾 きが増大し, 切断荷重は上昇して伸びが減少すること は明らかであるが，本実験範囲の衝撃速度では切断荷 重は静引張の場合に比べて $4 \sim 5.5 \mathrm{~m} / \mathrm{s}$ 程度で $3 \sim 5$ \%増加し, $7 \mathrm{~m} / \mathrm{s}$ 程度から 8〜10\%と急激に増加した が，伸びは概略速度の増加と比例して減少を示した。 また， $6 \times \mathrm{Fi}(19+6)$ 構造では逆に静の場合に比べて伸 びの増加を示したが，これは本ロープの然り長さがほ

Table 6 . Variation of absorbed energy with impact speed

\begin{tabular}{c|c|c|c|c}
\hline $\begin{array}{c}\text { Construction and } \\
\text { dia. of rope } \\
(\mathrm{mm})\end{array}$ & $\begin{array}{c}\text { Absorption } \\
\text { of energy in } \\
\text { static test } \\
(\mathrm{kg} \cdot \mathrm{m})\end{array}$ & \multicolumn{2}{|c}{$\begin{array}{c}\text { Absorption of } \\
\text { energy in impact } \\
\text { test }(\mathrm{kg} \cdot \mathrm{m})\end{array}$} \\
\cline { 2 - 5 } & $0.001 \mathrm{~m} / \mathrm{s}$ & $6 \cdot 7 \mathrm{~m} / \mathrm{s}$ & $5 \cdot 4 \mathrm{~m} / \mathrm{s}$ & $3 \cdot 9 \mathrm{~m} / \mathrm{s}$ \\
\hline $6 \times 7$ 0/L 16 & 525 & 500 & 533 & 485 \\
$6 \times 19 \% 16$ & 463 & 325 & 400 & 380 \\
$6 \times$ Fi (19+6)\% 16 & 270 & 375 & 480 & 433 \\
\hline
\end{tabular}

Rope length: $1000 \mathrm{~mm}$

Table 5 Variation of absorbed energy with rope length

\begin{tabular}{|c|c|c|c|c|c|c|}
\hline \multirow{2}{*}{$\begin{array}{l}\text { Construction and } \\
\text { dia. of rope } \\
(\mathrm{mm})\end{array}$} & \multicolumn{3}{|c|}{ Absorption of energy in static test } & \multicolumn{3}{|c|}{ Absorption of energy in impact test } \\
\hline & $\begin{array}{l}2000 \\
(\mathrm{~mm})\end{array}$ & $\begin{array}{l}1000 \\
(\mathrm{~mm})\end{array}$ & $\begin{array}{l}500 \\
(\mathrm{~mm})\end{array}$ & $\begin{array}{l}2000 \\
(\mathrm{~mm})\end{array}$ & $\begin{array}{l}1000 \\
(\mathrm{~mm})\end{array}$ & $\begin{array}{c}500 \\
(\mathrm{~mm})\end{array}$ \\
\hline $6 \times 7 \quad 0 / \mathrm{L} 16$ & 970 & 525 & 310 & 947 & 533 & 300 \\
\hline $6 \times 19 \% 16$ & 825 & 463 & 300 & 715 & 400 & 235 \\
\hline $6 \times \mathrm{Fi}(19+) \% 16$ & 510 & 270 & 168 & 625 & 480 & 283 \\
\hline
\end{tabular}


かの構造に比べて短かく, 静引張の場合, ストランド 間の接触圧に上る早期素線切断が影響したものと考え られる. 次に切断エネルギについては一般に静の場合 に比べて減少したが，本実験においていずれの場合も $5.4 \mathrm{~m} / \mathrm{s}$ の速度で一たん增加を示したことは，この範 囲の衝撃速度では切断エネルギにほとんど影響がない ことを示すものかと推定されるが，詳細は試料長さと の関連において今後なお検討を要するものと考えられ る。また， $6 \times \mathrm{Fi}(19+6)$ ロープが静の場合に比べて逆 にェネルギの增加を示したことについては上述の原因 も当然考えられることではあるが，われわれが以前に 行なった実験結果と綜合して今後進めて行きたいと考 えている耐衝撃性ロープの検討に興味ある結果と考え る。

\section{（II）長さを変化した場合}

長さを変化させた場合も速度を変えた場合と同様に 長さが短くなるほど切断荷重の上昇と伸びの減少を示 したが, 本実験の範囲では切断荷重において高の影 響が明りょうに認められた。すなわち,長さ $2000 \mathrm{~mm}$ から $1000 \mathrm{~mm}$ の変化では静の場合に比べて 2 〜\% 程度の增加であったが， $500 \mathrm{~mm}$ になると16〜18\% と急激に上昇した，伸びは各試験片の長さが変化する ので本結果から云々できないが，一般に静引張の場合 に比べて減少するということはできる。また，切断土 ネルギは長さが短くなるほど明りょうに隇少を示し， 本実験の範囲が限られており, かつ実験数の少ないこ とから数值五のものについての疑閣は残されるが，本 実験結果について構造別に実験式を示すと次の上うで ある。

$$
\begin{array}{ccc}
6 \times 7 \text { ロープ: } & y=1 \cdot 18 x^{0} \cdot 880 \\
6 \times 19 & \text { ロープ: } & y=1 \cdot 73 x^{0} \cdot 790 \\
6 \times \mathrm{Fi} & (1.9+6) & \text { ロープ : } y=6 \cdot 79 x^{0} \cdot 595 \\
\text { ただし } & y: \text { 切断エネルギ }(\mathrm{kg} \cdot \mathrm{m})
\end{array}
$$

すなわち、この結果から切断に至るまでのエネルギ は線数少なく，かつ線径の太い $6 \times 7$ ロープでは長さ に上るエネルギの変化は最も大きく, 線数多く, から 柔軟性に富む $6 \times \mathrm{Fi}(19+6)$ ロープでは比較的長さに よる土ネルギの変化が少ないということが考元られる。 なお切断位置については, 本実験範囲内の速度および 長さの変化では別段特定の傾向は認められず, 衝撃端
または固定端近傍で切断した場合もオシロ記録上での 差異は活とんどないようであった。

\section{7. 総括}

動荷重下におけるワイヤロープの強度ならびに一の 特性を究明するため, 新たに衝撃試験機を設計し, 衝 撃速度および長さを変化させた場合の強度およびェネ ルギの変化を測定し，静試験の場合と比較検討を行な った結果を総括して次のことが言えよう。

（1）試験機の構造上, 衝撃速度は $4 \sim 7 \mathrm{~m} / \mathrm{s}$, 長 さは 500 2 $000 \mathrm{~mm}$ の範囲でのみ実験を行なったが， 強度およびェネルギの変化では後者の方が明りょうに 影響することが認められた。

（2）衝撃速度の上昇, 長さの短縮とともに伸び荷重曲線の傾さが大になり，切断荷重は速度 $7 \mathrm{~m} / \mathrm{s}$ 位 から, また長さ $500 \mathrm{~mm}$ から急激に増加を示すが, 伸 びはほぼ比例的に滅少することが認められた。

（3）衝撃速度の上昇とともにエネルギは隇少する 傾向にあるが，本実験の範囲では明りょうな変化が認 められなかった。

（4）長さの短縮とともに切断に至るまでのエネル ギは滅少するが，本実験の範囲では相互間に対数相関 関係が考えられ, 線数少なく, かつ線径の太い $6 \times 7$ ロープは長さによるェネルギの変化が最も大で，線数 多く，かつ柔軟性に富む $6 \times \mathrm{Fi}(19+6)$ ロープでは長 さによるエネルギの変化が最も少ないということが認 められた。

（5） $6 \times \mathrm{Fi}(19+6)$ ロープでは静引張の場合に比べ て衙撃引張の場合，逆にェネルギが增大する傾向を示 し，原因についてなお検討の余地はあるが，耐衝撃性 ロープとして興味あることと考える。

（6）本実験範囲の速度および長さの変化では，切 断位置ならびに切断状沉に特定の傾向は認められず, 衝撃端または固定端近傍で切断した場合もオシ口記録 上での差異もほとんどなかった。

\section{参 考 文 献}

1）岡山千代田，立田潤，牧野豊，資源技術試騟所報（June 1960)

2）秋山英司, 近藤太二, 袷塚䐜三, 頓所進, 労働省産業安全研究 所報（1961）

3），作井誠太，中村正久，布村成具，鉄と鋼，第 47 年第 6 号（1961)

4) 藤井健也, 根来広平, 第 6 回材料試験連合講演会 (Oct. 1962) にて発表 